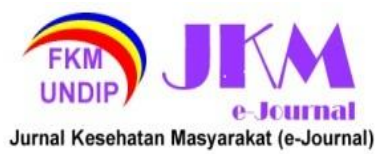

JURNAL KESEHATAN MASYARAKAT (e-Journal)

Volume 9, Nomor 6, November 2021

ISSN: 2715-5617 / e-ISSN: 2356-3346

http://ejournal3.undip.ac.id/index.php/jkm

\title{
GAMBARAN EPIDEMIOLOGI KEJADIAN DEMAM BERDARAH DENGUE: KARAKTERISTIK PENDERITA, WAKTU DAN FAKTOR LINGKUNGAN DI KECAMATAN TEMBALANG TAHUN 2019
}

\author{
Ikhwa Atika Sury $^{1^{*}}$, Martini Martini ${ }^{2}$, Sri Yuliawati ${ }^{2}$, Retno Hestiningsih ${ }^{2}$ \\ ${ }^{1}$ Peminatan Epidemiologi dan Penyakit Tropik, Fakultas Kesehatan Masyarakat, Universitas \\ Diponegoro, Jl. Prof. H. Soedarto, S.H.,Tembalang, Semarang, Indonesia \\ ${ }^{2}$ Bagian Epidemiologi dan Penyakit Tropik, Fakultas Kesehatan Masyarakat, Universitas Diponegoro, \\ J. Prof. H. Soedarto, S.H.,Tembalang, Semarang, Indonesia \\ *Corresponding author: ikhwa.atika@gmail.com
}

\begin{abstract}
Dengue Hemorrhagic Fever (DHF) is an endemic infectious disease in Tembalang District, Semarang. DHF is caused by dengue virus and transmitted by Aedes sp. mosquitoes especially Aedes aegypti. Patient characteristics, season, physical environmental factors and populations density is one of the risk factors for DHF transmission. This study aims to describe epidemiology of patient characteristics, time, physical environmental factors and population density on DHF incidence and analyze the correlation of factors and DHF incidence in Tembalang District. The type of this research is observasional descriptive with cross sectional study design. Samples of this research is 122 verified cases by Health Office Semarang City and they who live on Tembalang District. The epidemiological analysis obtained that the highest percentage of DHF patient is $61,5 \%$ in the male gender, $59 \%$ at the age of 4-12 years old and 63,1\% during the rainy season. The result of statistical analysis show that there is no correlation between area height $(p=0,084)$, temperature $(p=0,823)$, rainfall $(p=0,692)$, land use $(p=0,655)$ and population density $(p=0,387)$ with DHF incidence in Tembalang District at 2019.
\end{abstract}

\section{Keywords : patient characteristics, time, environmental factors, DHF}

\section{PENDAHULUAN}

Penyakit Demam Berdarah Dengue (DBD) adalah penyakit menular yang disebabkan oleh virus dengue (serotipe DEN-1, DEN-2, DEN-3, DEN-4) dan ditularkan kepada manusia melalui nyamuk Aedes sp. betina yang telah terinfeksi virus dengue terutama Aedes aegypti. Penyakit ini ditandai dengan demam mendadak dua sampai tujuh hari disertai gejala perdarahan dengan atau tanpa syok, perdarahan dan kebocoran plasma. ${ }^{(1),(2)}$

Penyakit DBD masih menjadi masalah kesehatan masyarakat di Provinsi Jawa Tengah. Incidence Rate (IR) di Provinsi Jawa Tengah mencapai 21,6 per 100.000 penduduk dengan Case Fatality Rate (CFR) sebesar 1,24\% pada tahun 2017 dan tahun 2018 mengalami penurunan IR menjadi 10,2 per 100.000 penduduk dengan CFR sebesar 1,05\%. Namun, pada tahun 2019 terjadi peningkatan IR menjadi 24,7 per 100.000 penduduk dengan CFR sebesar 1,34\%.(3),(4)

IR di Kota Semarang tahun 2017 mencapai 18,1 per 100.000 penduduk dengan CFR 2,68\% dan menurun menjadi 6,20 per 100.000 penduduk dengan CFR $1 \%$ pada tahun 2018, sedangkan tahun 2019 meningkat secara signifikan menjadi 26,37 per 100.000 penduduk dengan CFR 3,18\%. Berdasarkan data-data tersebut, Kecamatan Tembalang menjadi kecamatan dengan IR tertinggi selama tiga tahun berturut-turut di Kota Semarang yaitu 35,47 per 100.000 penduduk dengan CFR $3,28 \%$ pada tahun $2017,7,42$ per 100.000 penduduk dengan CFR $7,69 \%$ pada tahun 2018 dan 67,59 per 100.000 penduduk dengan CFR 0\% pada tahun 2019.(5),(6),(7)

Berdasarkan penelitian-penelitian sebelumnya beberapa faktor yang menjadi penyebab kasus DBD setiap tahun selalu ada di Kecamatan Tembalang antara lain karakteristik penderita yang mencakup umur, jenis kelamin, pendidikan dan pekerjaan, faktor lingkungan fisik yang mencakup ketinggian wilayah, perubahan curah hujan, suhu udara, kelembaban udara dan penggunaan lahan, serta faktor lingkungan sosiodemografi yang mencakup kepadatan penduduk dan mobilitas penduduk.

Pengendalian lingkungan dan vektor menjadi tumpuan dalam penanggulangan kejadian DBD di masyarakat. Maka, diperlukan penelitian lebih lanjut tentang DBD terutama mengenai gambaran epidemiologi karakteristik penderita, waktu kejadian, faktor lingkungan fisik, kepadatan penduduk, dan analisis hubungan terhadap kejadian DBD di Kecamatan Tembalang. 


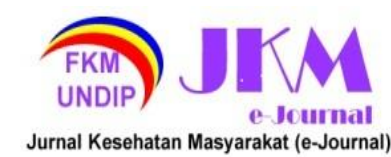

\section{METODE PENELITIAN}

Jenis penelitian yang digunakan adalah observasional deskriptif yang bertujuan untuk membuat gambaran mengenai epidemiologi karakteristik penderita, waktu kejadian dan faktor lingkungan pada kejadian DBD, dengan rancangan penelitian yaitu pendekatan cross sectional yang bertujuan untuk menganalisis hubungan antara faktor lingkungan dengan kejadian DBD.

Variabel bebas penelitian ini diantaranya umur, jenis kelamin, waktu kejadian, ketinggian wilayah, suhu udara, curah hujan, penggunaan lahan dan kepadatan penduduk, sedangkan variabel terikatnya adalah angka kejadian DBD di Kecamatan Tembalang.

Populasi dalam penelitian ini adalah 781 kasus yang terlapor sebagai demam berdarah sesuai yang tercatat oleh Dinas Kesehatan Kota Semarang (DKK Semarang) dan bertempat tinggal di Kecamatan Tembalang, sedangkan sampelnya yaitu 122 kasus yang terverifikasi sebagai DBD sesuai yang tercatat oleh DKK Semarang dan bertempat tinggal di Kecamatan Tembalang.

Data yang digunakan merupakan data sekunder yang diperoleh dari beberapa sumber, diantaranya data jumlah penderita, waktu kejadian, umur, jenis kelamin, jumlah penduduk, ketinggian wilayah, suhu udara, curah hujan, luas wilayah dan penggunaan lahan.

Pengolahan data dilakukan dengan tahapan yaitu editing, coding, entry data, cleaning dan tabulating, serta analisis data yang digunakan yaitu analisis epidemiologi melalui cross tab, distribusi frekuensi dan dilakukan uji korelasi pearson.

\section{HASIL DAN PEMBAHASAN}

Tabel 1 Incidence Rate DBD di Kecamatan Tembalang 2019

\begin{tabular}{clrr}
\hline No. & Kelurahan & $\begin{array}{c}\text { Jumlah } \\
\text { Penderita }\end{array}$ & \multicolumn{1}{c}{ IR } \\
\hline 1. & Bulusan & 1 & 16,70 \\
2. & Kramas & 6 & 160,17 \\
3. & Tembalang & 0 & 0,00 \\
4. & Meteseh & 15 & 69,02 \\
5. & Rowosari & 12 & 96,92 \\
6. & Sendangmulyo & 26 & 68,70 \\
7. & Mangunharjo & 3 & 28,25 \\
8. & Sambiroto & 8 & 52,40 \\
9. & Tandang & 14 & 56,62 \\
10. & Kedungmundu & 10 & 81,24 \\
11. & Sendangguwo & 22 & 97,67 \\
12. & Jangli & 5 & 65,01 \\
\hline & Total & 122 & 67,59 \\
\hline
\end{tabular}

Berdasarkan analisis epidemiologi, IR

DBD Kecamatan Tembalang tahun 2019 sebesar 67,59 per 100.000 penduduk. IR DBD tertinggi terjadi di Kelurahan Kramas yaitu sebesar 160,17 per 100.000 penduduk, sedangkan IR DBD terendah terjadi di Kelurahan Tembalang yaitu sebesar 0 per 100.000 penduduk atau dengan kata lain tidak ada kasus DBD di Kelurahan Tembalang.

Tabel 2. Distribusi Frekuensi Berdasarkan Jenis Kelamin Penderita dan Waktu Kejadian DBD di Kecamatan Tembalang Tahun 2019

\begin{tabular}{|c|c|c|c|c|c|c|c|c|c|c|}
\hline \multirow{3}{*}{ No. } & \multirow{3}{*}{ Kelurahan } & \multicolumn{8}{|c|}{ Jenis Kelamin } & \multirow{3}{*}{ IR } \\
\hline & & \multicolumn{4}{|c|}{ Laki-laki Perempuan } & \multicolumn{4}{|c|}{$\begin{array}{cc}\text { Musim } & \text { Musim } \\
\text { Hujan } & \text { Kemarau }\end{array}$} & \\
\hline & & $f$ & $\%$ & $f$ & $\%$ & 1 & $\%$ & $f$ & $\%$ & \\
\hline 1. & Bulusan & & 0,8 & 0 & 0,0 & & 0,8 & 0 & 0,0 & 16,70 \\
\hline 2. & Kramas & 5 & 4,1 & 1 & 0,8 & 5 & 4,1 & 1 & 0,8 & 160,17 \\
\hline 3. & Tembalang & 0 & 0,0 & 0 & 0,0 & 0 & 0,0 & 0 & 0,0 & 0,00 \\
\hline 4. & Meteseh & 6 & 4,9 & 9 & 7,4 & 12 & 9,8 & 3 & 2,5 & 69,02 \\
\hline 5. & Rowosari & 7 & 5,7 & 5 & 4,1 & 4 & 3,3 & 8 & 6,6 & 96,92 \\
\hline 6. & Sendangmulyo & 13 & 10,7 & 13 & 10,7 & 17 & 13,9 & 9 & 7,4 & 68,70 \\
\hline 7. & Manqunhario & 3 & 2,5 & 0 & 0,0 & 0 & 0,0 & 3 & 2,5 & 28,25 \\
\hline
\end{tabular}




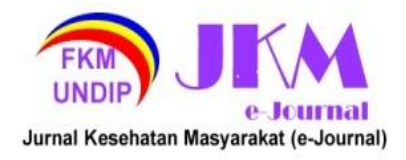

JURNAL KESEHATAN MASYARAKAT (e-Journal)

Volume 9, Nomor 6, November 2021

ISSN: 2715-5617 / e-ISSN: 2356-3346

http://ejournal3.undip.ac.id/index.php/jkm

\begin{tabular}{|c|c|c|c|c|c|c|c|c|c|c|}
\hline 8. & Sambiroto & 4 & 3,3 & 4 & 3,3 & 2 & 1,6 & 6 & 4,9 & 52,40 \\
\hline 9. & Tandang & 9 & 7,4 & 5 & 4,1 & 10 & 8,2 & 4 & 3,3 & 56,62 \\
\hline 10. & Kedungmundu & 7 & 5,7 & 3 & 2,5 & 6 & 4,9 & 4 & 3,3 & 81,24 \\
\hline 11. & Sendangguwo & 16 & 13,1 & 6 & 4,9 & 15 & 12,3 & 7 & 5,7 & 97,67 \\
\hline 12. & Jangli & 4 & 3,3 & 1 & 0,8 & 5 & 4,1 & 0 & 0,0 & 65,01 \\
\hline & Total & 75 & 61,5 & 47 & 38,5 & 77 & 63,1 & 45 & 36,9 & 67,59 \\
\hline
\end{tabular}

Tabel 3 Distribusi Frekuensi Berdasarkan Umur Penderita DBD di Kecamatan Tembalang Tahun 2019

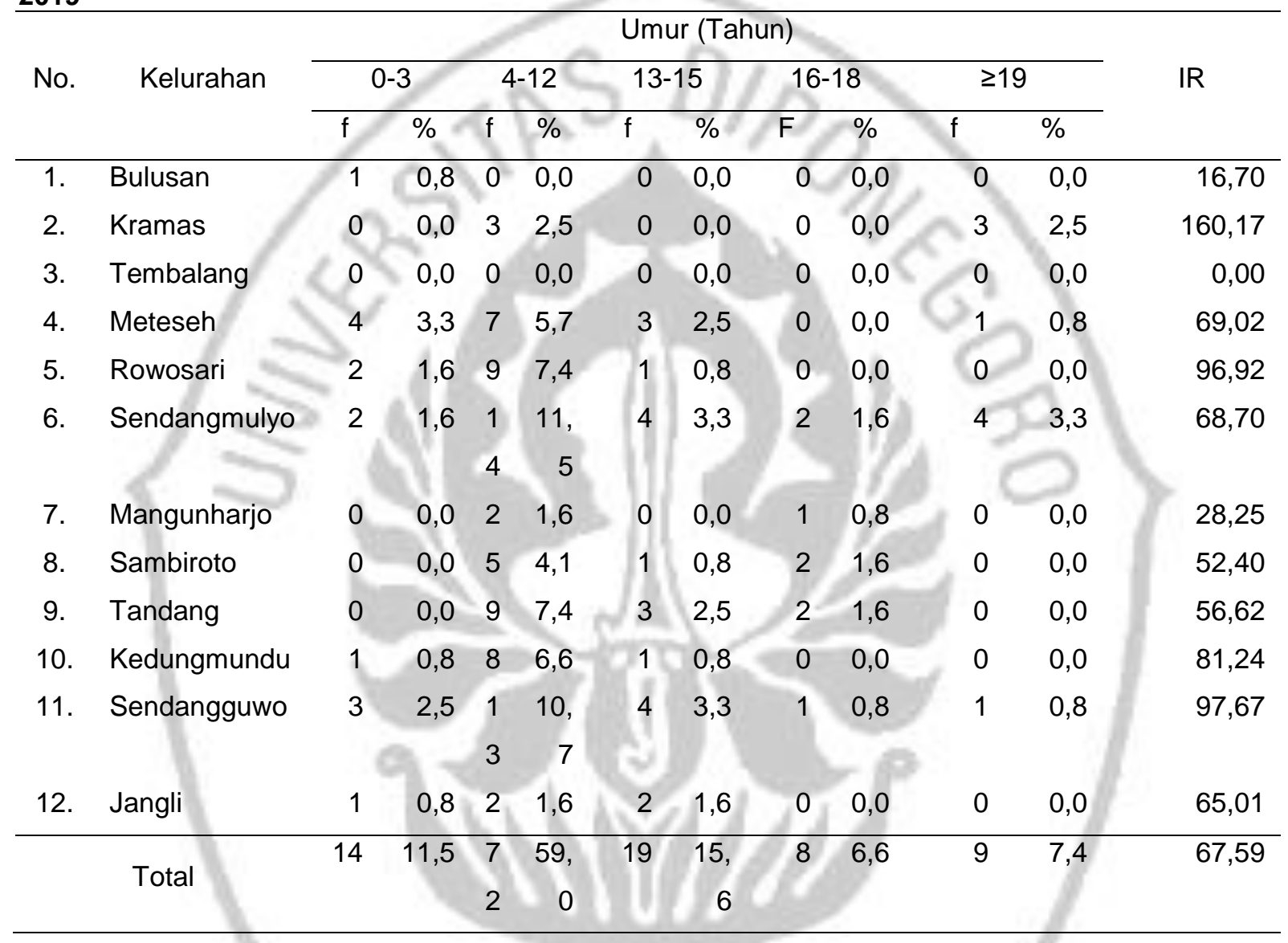

Berdasarkan hasil analisis epidemiologi data kasus DBD di Kecamatan Tembalang tahun 2019, pasien terbanyak dari jenis kelamin laki-laki sebanyak $61,5 \%$ yaitu Kelurahan Sendangguwo sebesar $13,1 \%$. Hal ini dapat dikarenakan produksi imunoglobin dan antibodi dikelola secara genetika dan hormonal, sehingga perempuan lebih efisien dalam memproduksi imunoglobin dibandingkan laki-laki.(8) Hasil penelitian ini sejalan dengan penelitian yang dilakukan oleh Bibah dkk pada tahun 2017 di Wilayah Kerja Puskesmas Celikah Kabupaten Ogan Komering Ilir. ${ }^{(9)}$

Pasien terbanyak selanjutnya dari kelompok usia 4-12 tahun sebanyak 59\% yaitu Kelurahan Sendangmulyo sebesar 11,5\%.
Kelompok usia 4-12 tahun paling banyak tertular DBD karena pola kegiatan anak-anak tersebut sesuai dengan pola puncak aktivitas Aedes aegypti yaitu pukul 08.00 - 09.00, pada pukul ini anak-anak berada di lingkungan sekolah, dan 16.00 - 17.00, anak-anak berada di lingkungan rumah.(10),(11) Penelitian ini sejalan dengan penelitian yang dilakukan oleh Oksfriani pada tahun 2020 di Kabupaten Minahasa. ${ }^{(12)}$

Berdasarkan waktu kejadian, kasus DBD paling banyak terjadi saat musim hujan sebanyak $63,1 \%$ yaitu Kelurahan Sendangmulyo sebesar $13,9 \%$. Hal ini disebabkan pada saat musim hujan, container yang tidak bisa dikendalikan (disposable site) 


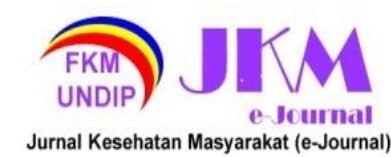

terisi air hujan sehingga container tersebut menjadi tempat perindukan yang strategis untuk nyamuk Aedes aegypti.(13) Penelitian ini sejalan dengan penelitian yang dilakukan oleh Oksfriani pada tahun 2020 di Kabupaten Minahasa yang menunjukkan bahwa DBD terjadi saat musim hujan, tahun 2016 terjadi
JURNAL KESEHATAN MASYARAKAT (e-Journal)

Volume 9, Nomor 6, November 2021

ISSN: 2715-5617 / e-ISSN: 2356-3346

http://ejournal3.undip.ac.id/index.php/jkm

Tabel 4. Distribusi Ketinggian Wilayah, Suhu Udara, Curah Hujan, Penggunaan Lahan Bangunan dan Kepadatan Penduduk di Kecamatan Tembalang Tahun 2019

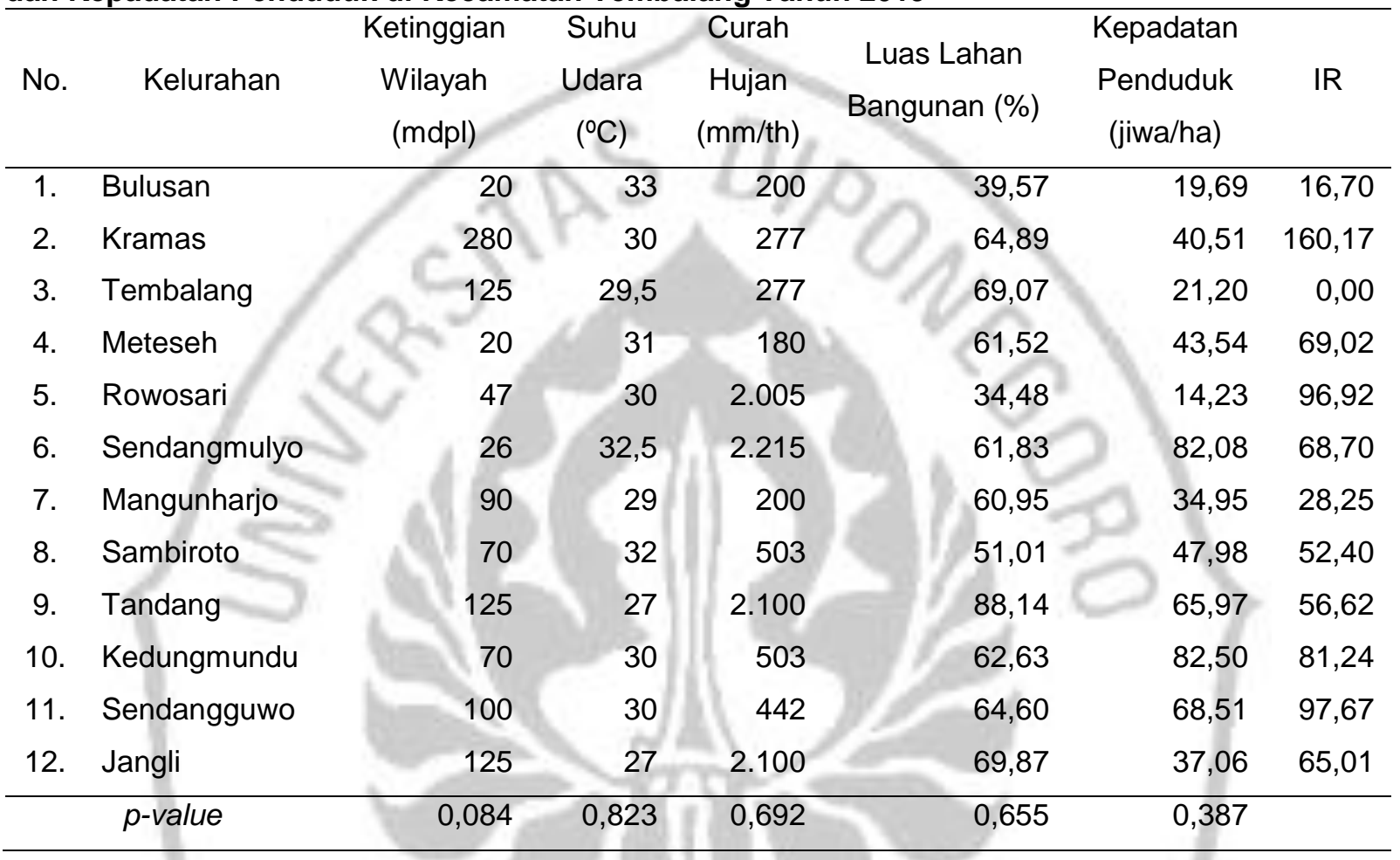

Berdasarkan hasil uji statistik menggunakan uji korelasi pearson, diperoleh $p$ value dari faktor ketinggian wilayah adalah 0,084 , karena $p$-value $>0,05$ artinya tidak ada hubungan yang bermakna antara ketinggian wilayah dengan kejadian DBD di Kecamatan Tembalang tahun 2019. Hal ini dikarenakan penelitian menggunakan rata-rata ketinggian wilayah Kecamatan Tembalang, sehingga tidak dapat menggambarkan ketinggian wilayah di rumah penderita. Rata-rata ketinggian wilayah Kecamatan Tembalang yaitu 91,5 mdpl, artinya wilayah Kecamatan Tembalang merupakan dataran rendah. Penelitian ini sejalan dengan penelitian yang dilakukan oleh Ulfa dkk di Kota Semarang yang menunjukkan bahwa ketinggian wilayah tidak berkontribusi terhadap persebaran kasus DBD di Kota Semarang dalam kurun waktu 4 tahun (2016-2019).(14)

Hasil uji korelasi pearson menunjukkan $p$-value dari faktor suhu udara adalah 0,823 yang berarti tidak ada hubungan yang bermakna antara suhu udara dengan kejadian pada awal tahun yaitu bulan Januari-Februari sebanyak 9 kasus, tahun 2017 terjadi pada bulan Januari-Mei sebanyak 13 kasus dan kejadian DBD mengalami kecenderungan peningkatan kasus pada pertengahan hingga akhir tahun 2018. ${ }^{(12)}$ 


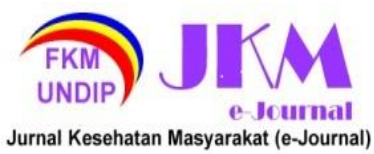

Kecamatan Tembalang yaitu $921 \mathrm{~mm} / \mathrm{th}$, artinya Kecamatan Tembalang memiliki curah hujan yang tinggi. Penelitian ini sejalan dengan penelitian Arifatun tahun 2018 yang menyatakan bahwa tidak ada hubungan yang bermakna antara curah hujan dengan kejadian DBD di Kabupaten Karanganyar. ${ }^{(19)}$

Hasil uji korelasi pearson menunjukkan $p$-value dari faktor luas penggunaan lahan untuk bangunan adalah 0,655 artinya tidak ada hubungan yang bermakna antara luas penggunaan lahan untuk bangunan dengan kejadian DBD di Kecamatan Tembalang tahun 2019. Hal ini dapat dikarenakan vektor nyamuk sudah beradaptasi dengan kondisi lingkungan sehingga terjadi perubahan pola penularan penyakit DBD.(20) Persentase luas penggunaan lahan untuk bangunan yaitu $60,71 \%$ dari luas wilayah Kecamatan Tembalang. Penelitian ini sejalan dengan penelitian yang dilakukan oleh Marlena dkk Kota Banda Aceh tahun 2019 yang menunjukkan bahwa tidak ada hubungan kepadatan dan luas permukiman dengan pola sebaran DBD. (21)

Berdasarkan hasil uji korelasi pearson, diperoleh $p$-value dari faktor kepadatan penduduk adalah 0,387 berarti tidak ada hubungan yang bermakna antara kepadatan penduduk dengan kejadian DBD di Kecamatan Tembalang tahun 2019. Hal ini karena kepadatan penduduk hanya merupakan salah satu faktor risiko yang bersama dengan faktor risiko lainnya seperti faktor dari host, agent, vektor, lingkungan dan perilaku secara keseluruhan yang dapat menyebabkan terjadinya penularan DBD. (22) Rata-rata kepadatan penduduk Kecamatan Tembalang yaitu 46,51 jiwa/ha, artinya kepadatan penduduk Kecamatan Tembalang rendah. Penelitian ini sejalan dengan penelitian Suhermanto dan Suparmi di Kota Jambi tahun 2017 yang menyatakan bahwa secara korelasi dibuktikan bahwa hubungan kepadatan penduduk dengan kejadian DBD adalah lemah dan tidak signifikan. ${ }^{(23)}$

\section{KESIMPULAN}

Persentase penderita DBD terbanyak sebesar $61,5 \%$ pada jenis kelamin laki-laki, sebesar $59 \%$ pada usia 4-12 tahun (usia TKSD) dan $63,1 \%$ pada musim hujan (Bulan Januari-April, Lingkungan

November-Desember). mempunyai suhu udara $30,08^{\circ} \mathrm{C}$, ketinggian wilayah 91,5 mdpl, curah hujan $921 \mathrm{~mm} / \mathrm{tahun}$, penggunaan lahan 198,86 ha dan kepadatan penduduk 46,51 jiwa/ha. Tidak ada korelasi antara ketinggian wilayah $(p=0,084)$, suhu udara $(p=0,823)$, curah hujan $(p=0,692)$, penggunaan lahan $(p=0,655)$ dan kepadatan penduduk $(p=0,387)$ dengan kejadian DBD di Kecamatan Tembalang.

\section{SARAN}

Diharapkan masyarakat untuk meningkatkan praktik pencegahan dan pengendalian $\mathrm{DBD}$, misalnya dengan cara rutin dan konsisten melaksanakan PSN, DKK Semarang dan Kecamatan Tembalang disarankan untuk meningkatkan program PSN dengan memberikan penyuluhan tentang pentingnya keaktifan masyarakat dalam melaksanakan PSN, melakukan kontrol terhadap pertumbuhan dan perpindahan penduduk.

\section{DAFTAR PUSTAKA}

1. Departemen Kesehatan Republik Indonesia. Tata Laksana Demam Berdarah Dengue di Indonesia. Ketiga. Jakarta: Departemen Kesehatan Republik Indonesia; 2004. 1-62 p.

2. Fidayanto R, Susanto $H$, Yohanan $A$, Yudhastuti R. Modul Pengendalian Demam Berdarah Dengue. Handoko D, Prasetyowati EB, Hartoyo S, editors. Kesmas Natl Public Heal J. 2013;7(11):522.

3. Dinas Kesehatan Provinsi Jawa Tengah. Profil Kesehatan Provinsi Jawa Tengah Tahun 2018. Vol. 5. Jawa Tengah: Dinas Kesehatan Provinsi Jawa Tengah; 2017. 1$8 \mathrm{p}$.

4. Profil Kesehatan Provinsi Jawa Tengah. Profil Kesehatan Provinsi Jateng Tahun 2019. Vol. 3511351. Jawa Tengah: Dinas Kesehatan Provinsi Jawa Tengah; 2019. 273-275 p.

5. Dinas Kesehatan Kota Semarang. Semarang City Health Profile 2017. Semarang: Dinas Kesehatan Kota Semarang; 2017. 18 p.

6. Dinas Kesehatan Kota Semarang. Profil Kesehatan Kota Semarang 2018. Semarang: Dinas Kesehatan Kota Semarang; 2018. 15-68 p.

7. Dinas Kesehatan Kota Semarang. Profil Kesehatan Kota Semarang 2015. Semarang: Dinas Kesehatan Kota Semarang; 2018. 1-104 p.

8. Herawati YT. Karakteristik Penderita Demam Berdarah Dengue di RS dr. Kariadi Semarang Tahun 2008. Universitas Negeri Semarang; 2008.

9. Novrita B, Mutahar R, Purnamasari I. Analisis Faktor Risiko Kejadian Demam 


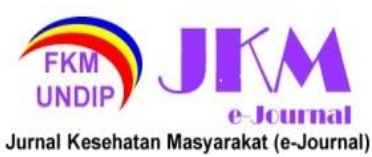

Berdarah Dengue di Wilayah Kerja Puskesmas Celikah Kabupaten Ogan Komering llir. J IImu Kesehat Masy. 2017;8(1):19-27.

10. Mayasari $R$, Arisanti $M$, Nurmaliani $R$, Sitorus H, Ambarita LP. Karakteristik Penderita, Hari dan Curah Hujan terhadap Kejadian Demam Berdarah di Kabupaten Ogan Komering Ulu. J Heal Epidemiol Commun Dis. 2020;5(1):23-9.

11. Pertiwi PI, Anwar C. Gambaran Epidemiologi Kejadian Penyakit Demam Berdarah Dengue di Kecamatan Buah Batu Kota Bandung Tahun 2012-2016. Keslingmas. 2016;37(3):240-404.

12. Tamengkel HV, Sumampouw OJ, Pinontoan OR. Ketinggian Tempat dan Kejadian Demam Berdarah Dengue. Indones J Public Heal Community Med. 2020;1(1):12-8.

13. Prasetyowati $\mathrm{H}$, Astuti EP, Hendri J, Fuadzy H. Risiko Penularan DBD Berdasarkan Maya Index dan Key Container pada Rumah Tangga Kasus dan Kontrol di Kota Bandung. Balaba J Litbang Pengendali Penyakit Bersumber Binatang Banjarnegara. 2018;14(2):181-90.

14. Alfiyanti, UN.; Siwiendrayanti A. Analisis Spasial dan Temporal Kejadian DBD di Kota Semarang Tahun 2016-2019. J Kesehat Lingkung. 2021;18(1):39-48.

15. Vidiyani A, Yudhastuti R. Hubungan Kondisi Lingkungan, Kontainer, dan Perilaku Masyarakat dengan Keberadaan Jentik Nyamuk Aedes aegypti di Daerah Endemis Demam Berdarah Dengue Surabaya. J Kesehat Lingkung Unair. 2005;1(2):3942.

16. Ayun LL. Hubungan antara Faktor Lingkungan Fisik dan Perilaku dengan Kejadian Demam Berdarah Dengue (DBD) di Wilayah Kerja Puskesmas Sekaran, Kecamatan Gunungpati, Kota Semarang Tahun 2015. Vol. 1, Ilmu Kesehatan Masyarakat UNNES. Universitas Negeri Semarang; 2015.

17. Bangkele EY, Safriyanti N. Hubungan Suhu dan Kelembaban dengan Kejadian Demam Berdarah Dengue (DBD) di Kota Palu Tahun 2010-2014. J IIm Kedokt. 2016;3(2):40-50.

18. Sari M. Perkembangan dan Ketahanan Hidup Larva Aedes aegypti pada Beberapa Media Air yang Berbeda. Skripsi. Universitas Lampung. Universitas Lampung; 2017.

19. Nisaa A. Korelasi Antara Faktor Curah Hujan dengan Kejadian DBD Tahun 2010-
2014 Di Kabupaten Karanganyar. Ikesma. 2018;14(1):25.

20. Irda Sari SY, Adelwin Y, Rinawan FR. Land Use Changes and Cluster Identification of Dengue Hemorrhagic Fever Cases in Bandung, Indonesia. Trop Med Infect Dis. 2020;5(2):1-9.

21. Daud M. Hubungan Kepadatan Permukiman Dengan Luas Permukiman Terhadap Sebaran Demam Berdarah Dengue. J Sain Vet. 2020;38(2):112.

22. Wahyuni C, Keman S, Fathi F. Peran Faktor Lingkungan dan Perilaku terhadap Penularan Demam Berdarah Dengue di Kota Mataram. J Kesehat Lingkung Unair. 2005;2(1):3944.

23. Suhermanto, Suparmi. Demam Berdarah Dengue Berdasarkan Kepadatan Penduduk dan Curah Hujan. J Bahana Kesehat Masy. 2017;1(1):75-86. 